\title{
DOBRO MAŁŻONKÓW JAKO PRZEDMIOT SYMULACJI ZGODY MAŁŻEŃSKIEJ
}

\begin{abstract}
Streszczenie. Kodeks prawa kanonicznego z 1983 r. definiuje trzy grupy przyczyn stwierdzenia nieważności małżeństwa: przeszkody zrywające, wady zgody małżeńskiej i wady formy kanonicznej. Pośród różnych wad zgody małżeńskiej w kan. 1101 § KPK Prawodawca wymienia różne formy symulacji. Symulacja oznacza, że kontrahent zawiera małżeństwo jedynie zewnętrznie, wykluczając małżeństwo jako takie lub jakiś jego istotny element lub przymiot. Niniejszy artykuł stanowi próbę określenia jednej z form symulacji częściowej, określanej jako wykluczenie dobra małżonków, z uwzględnieniem sposobu jego dowodzenia.
\end{abstract}

Słowa kluczowe: małżeństwo, zgoda małżeńska, symulacja, dobro małżonków, wykluczenie.

Pośród różnych wad zgody małżeńskiej prawodawca w kan. 1101 § KPK wymienia symulację zgody małżeńskiej. Symulacja oznacza, iż osoba zawierająca małżeństwo wyraża zgodę małżeńską jedynie pozornie, zewnętrznie, w rzeczywistości wykluczając pozytywnym aktem woli samo małżeństwo lub któryś z jego przymiotów czy elementów. Symulujący dopuszcza się symulacji dla ściśle określonego celu lub celów, stąd charakterystyczna dla tej wady zgody małżeńskiej jest tzw. causa simulandi, czyli przyczyna, dla której dana osoba postanawia pozytywnym aktem woli wykluczyć małżeństwo jako takie lub jeden z jego przymiotów czy celów, zachowując jednocześnie zewnętrzne pozory.

Tytuł wykluczenia dobra małżonków stanowi novum w odniesieniu do Kodeksu prawa kanonicznego z 1917 r. W starym kodeksie prawodawca, mówiąc o symulacji zgody małżeńskiej, wskazywał jedynie na trzy tytuły symulacji częściowej, a mianowicie: wykluczenie prawa do aktów małżeńskich oraz wykluczenie jedności i nierozerwalności małżeństwa.

Obecnie obowiązujący Kodeks prawa kanonicznego pod pojęciem symulacji częściowej rozumie wykluczenie jakiegoś istotnego elementu małżeństwa lub jakiegoś istotnego przymiotu małżeństwa. Istotne przymioty małżeństwa to jedność i nierozerwalność, i w tym temacie obecny kodeks powtarza odpowiednią normę kodeksu z 1917 r. Istotne elementy małżeństwa to przede wszystkim zawarte w kan. 1055 KPK dwa cele małżeństwa, czyli zrodzenie i wychowanie potomstwa oraz dobro małżonków (bonum coniugum).

* Uniwersytet Łódzki, Wydział Prawa i Administracji, Katedra Teorii i Filozofii Prawa, gleszczynski@wpia.uni.lodz.pl. 
Rota Rzymska w swoim orzecznictwie wydała niewiele wyroków z tytułu wykluczenia dobra małżonków. Zakładając jednak, że tytuł wykluczenia dobra małżonków pojawi się w bliskiej przyszłości w orzecznictwie Roty Rzymskiej, z większym natężeniem spróbujmy zastanowić się nad przedmiotem i sposobem dowodzenia wykluczenia tego elementu małżeństwa na podstawie dostępnych środków dowodowych, a zatem nad relacją zachodzącą pomiędzy ważnością ma1żeństwa a wykluczeniem dobra małżonków.

\section{BONUM CONIUGUM}

Bez wątpienia niezwykle istotnym momentem w spojrzeniu na kwestię dobra bonum coniugum był Sobór Watykański II. Określając małżeństwo jako wspólnotę życia i miłości małżeńskiej, sobór odstąpił od jedynie prokreacyjnej, a zarazem jurydycznej wizji małżeństwa, ukazując przy tym, iż małżeństwo jest przede wszystkim wspólnotą miłości, w której więź międzyosobowa stanowi element niezwykle istotny. Personalistyczna wizja małżeństwa, tak charakterystyczna dla odnowy soborowej, musiała doprowadzić do zupełnie innego spojrzenia ojców soboru na podstawowe cele małżeństwa, spośród których ordinatio ad prolem nie mogło być już rozumiane jako cel absolutnie pierwszorzędny, gdyż cel ten musiał być interpretowany w kontekście małżeństwa rozumianego jako wspólnota życia i miłości.

Już w Konstytucji dogmatycznej o Kościele Lumen gentium czytamy m.in., że „małżonkowie chrześcijańscy na mocy sakramentu małżeństwa, przez który wyrażają tajemnicę jedności i płodnej miłości pomiędzy Chrystusem i Kościołem oraz w niej uczestniczą, wspomagają się wzajemnie we współżyciu małżeńskim oraz rodzeniu i wychowaniu potomstwa dla zdobycia świętości" (Lumen gentium, 11).

Konstytucja duszpasterska o Kościele w świecie współczesnym Gaudium et spes w sposób jednoznaczny mówi o ,głębokiej wspólnocie życia i miłości małżeńskiej”. Jak czytamy: „Z samej zaś natury swojej instytucja małżeńska oraz miłość małżeńska nastawione są na rodzenie i wychowanie potomstwa, co stanowi jej jakby szczytowe uwieńczenie. W ten sposób mężczyzna i kobieta [...] świadczą sobie wzajemnie pomoc i posługę oraz doświadczają sensu swej jedności i osiągają ją w coraz pełniejszej mierze" (Gaudium et spes, 48).

Schematy nowego Kodeksu prawa kanonicznego, który został promulgowany w 1983 r., uwzględniały nie tylko odnowioną wizję małżeństwa zaprezentowaną przez Sobór Watykański II, w omawianym tutaj temacie szczególnie w Konstytucji Gaudium et spes, lecz także osiągnięcia jurysprudencji Roty Rzymskiej, która począwszy od lat 70. XX w. podjęła próbę zdefiniowania pojęcia bonum coniugum w odniesieniu do celów małżeństwa (Sent. coram Fagiolo 1970, 878-890; Sent. coram Pinto 1980, 393).

Bonum coniugum rozumiane jako cel małżeństwa pojawia się po raz pierwszy w pracach Komisji przygotowującej nowy Kodeks prawa kanonicznego w roku 
1977. Konsultorzy, odnosząc się do kan. 243 Schematu z 1975 r., bardzo krytykowanego przez doktrynę ze względu na nieuwzględnienie osiągnięć soboru i jurysprudencji w odniesieniu do personalistycznej wizji małżeństwa, zaproponowali definicję małżeństwa, w której zarówno dobro małżonków, jak i zrodzenie oraz wychowanie potomstwa zostają postawione na równej płaszczyźnie („Matromonium est viri et mulieris totius vitae coniunctio quae indole sua naturali ad bonum coniugum atque ad prolis procreationem et educationem ordinatur" - Pontificia Commisio Iuris Canonici Reconoscendo 1977, 123). Co więcej, definicja zaproponowana w 1977 r. spotkała się z uznaniem, skoro w żadnym calu nie została już zmieniona (Pontificia Commisio Iuris Canonici Reconoscendo 1983, 221).

Prawodawca w Kodeksie prawa kanonicznego z 1983 r. w kan. 1055 wskazuje na dwa cele małżeństwa: dobro małżonków oraz zrodzenie i wychowanie potomstwa. Warto zauważyć, że w definicji małżeństwa zawartej w kan. 1055 KPK nie znajdujemy żadnego rozróżnienia pomiędzy celem pierwszorzędnym i celem drugorzędnym małżeństwa. Co więcej, jak się wydaje, nie można też mówić o jakiejkolwiek preferencji prawodawcy co do podkreślania któregoś z celów małżeństwa, zwłaszcza że obydwa cele w praktyce przenikają się wzajemnie, współtworząc relację miłości między małżonkami.

Jakkolwiek wydaje się, iż termin bonum coniugum, oznaczający jeden z dwóch celów małżeństwa zgodnie z kan. $1055 \mathrm{KPK}$, na stałe pojawił się w doktrynie prawnej, to jego bliższe określenie przysparza wiele trudności. Być może taki jest powód trudności, z jakimi boryka się również jurysprudencja w odniesieniu do określenia odrębności tytułu wykluczenia dobra małżonków. Jak należy przypuszczać, problemem jest sprecyzowanie, czy termin bonum coniugum odnosi się do esencji małżeństwa, inaczej mówiąc - do małżeństwa ujmowanego w jego aspekcie in fieri, czy raczej do małżeństwa ujmowanego in facto esse, oznaczającego etap, który następuje po wyrażeniu zgody małżeńskiej, z całym wysiłkiem małżonków ukierunkowanym na stworzenie wspólnoty życia (Bertolino 1996, 12).

Momentem początkowym powstania związku małżeńskiego jest ten, w którym dwie osoby przeciwnej płci wyrażają zgodę małżeńską, w ten sposób oddając się sobie nawzajem. Małżeństwo jest związkiem mężczyzny i kobiety z natury swojej skierowanym na dobro małżonków. I odwrotnie, właśnie owo dobro małżonków jest głównym elementem małżeństwa. Skro tak, to znaczy, że nie może zaistnieć sytuacja, aby małżonkowie, zawierając związek małżeński, mogli nie pragnąć swojego dobra, gdyż owo dobro jest jednoznaczne z przedmiotem, na którym opiera się zgoda małżeńska. Tymże przedmiotem - zgodnie z kan. 1057 KPK - jest wzajemne przyjęcie i przekazanie siebie sobie nawzajem przez współmałżonków (tamże, 17).

Dobro małżonków nie jest rzeczywistością obiektywną, ale osobową, gdyż możliwą do zrealizowania jedynie przez osoby współmałżonków. Co więcej, nie jest to dobro abstrakcyjne, gdyż jest dobrem właśnie dla konkretnych osób, które decydują się na stworzenie wspólnoty życia (tamże, 18-19). 
Owo oddanie się małżonkowi zawiera nie tylko aspekt fizyczny, ale winno być rozumiane w kontekście całej osoby i jest przezwyciężeniem własnego egoizmu w celu otwarcia się na dialog z drugą osobą. Małżonkowie oddają sobie nawzajem nie to, co posiadają, ale to, kim są - swoją osobę. Ponadto jest to oddanie się całkowite, niedopuszczające jakichkolwiek wyjątków. Każdy wyjątek byłby bowiem zaprzeczeniem całkowitego oddania się w sensie ostatecznym i wyłącznym (Bonnet 1996, 112-116).

Niezbędne jest, aby małżonkowie nie tylko pragnęli dobra w momencie wyrażania zgody małżeńskiej, lecz także ukierunkowali swoje działanie na osiągnięcie celu, do którego zdążają. Wzajemne oddanie się małżonków w małżeństwie ukierunkowane na stworzenie wspólnoty życia i miłości, będące esencją małżeństwa rozumianego in fieri, zawiera bowiem w sobie ukierunkowanie na bonum coniugum w małżeństwie ujętym jako in facto esse. Można zatem pokusić się o stwierdzenie, że poprzez wzajemną wspólnotę życia małżonków bonum coniugum się kształtuje i nabiera odpowiedniej formy. Co więcej, to właśnie małżeństwo jest rzeczywistością, która pozwala małżonkom wzrastać w doskonałości osobowej i poprzez to stawać się dobrem dla drugiej osoby (tamże, 127-128). Zatem bonum coniugum jest ostatecznym punktem długiego procesu wzajemnego dojrzewania i tworzenia pełnej wspólnoty życia i miłości. To oznacza, iż jest ono oparte na całej gamie wartości umożliwiających wzajemne doskonalenie się w relacji interpersonalnej - wartości uczuciowych, intelektualnych, ekonomicznych, tych o charakterze kulturowym i przede wszystkim duchowym (Gajda 2000, 30)1. Idzie tu więc zarówno o wspólnotę w sferze seksualnej, jak i w codziennym przeżywaniu wspólnych problemów, trudności, które pozornie wydawać się mogą dalekie od tworzenia wspólnoty, zaś w praktyce przezwyciężane wspólnym wysiłkiem taką wspólnotę ubogacają i zbliżają do doskonałości (Viladrich 2002, 319)².

${ }^{1}$ P. M. Gajda stwierdza, iż pod pojęciem , dobra małżonków: należy rozumieć: intymne pożycie małżonków, ich duchową jedność, wzajemną pomoc, doskonalenie osobowości współmałżonków oraz wzajemne uświęcenie”. Podobnie R. Bertolino: „Trattasi [...] della piena relazione intra e interpersonale, realizzata nella reciproca dedizione, voluta nella donazione d'amore, che fa il bene dell'altro (oltre che proprio), nella comunione delle persone e, specialmente, alla santificazione e quasi consacrazione dei coniugi, nel ministero ecclesiale della famiglia" (Bertolino 1996, 29).

${ }^{2}$ Jak napisał P. J. Viladrich: „Jako celowość - ordinatio ad finem - ma charakter potencjalnej dynamiki intymnej wspólnoty życia, która będzie się realizować w całym życiu małżeństwa, chociaż ustanawia się jako potencja w chwili powstania związku. Małżonkowie są sobie winni akty i wzajemne uczynki pomocy i wsparcia, zdatne i konieczne do tego, by dynamika życia małżeńskiego skierowała się do uporządkowanej realizacji małżeńskiego sensu płciowości, a w sensie negatywnym, ze sprawiedliwości winni unikać tego wszystkiego, co dezintegruje i rozbija elementy fizyczno-psychiczne i duchowe pociągu płciowego w intymnej wspólnocie małżeńskiej”. 


\section{DOBRO MAŁŻONKÓW JAKO PRZEDMIOT SYMULACJI CZEŚCIOWEJ}

Prawodawca w kan. 1101 KPK w paragrafie 1 stwierdza, że domniemywa się, iż wewnętrzna zgoda odpowiada słowom lub znakom użytym przy zawieraniu małżeństwa. Zawarte w paragrafie 1 kan. 1101 KPK domniemanie prawne zakłada, że słowa lub znaki użyte przez nupturientów w trakcie wyrażania zgody małżeńskiej odpowiadają ich wewnętrznemu przekonaniu, czyli wewnętrznej zgodzie. Sytuacja przeciwna, wyrażająca się w niezgodności pomiędzy stanem wewnętrznym człowieka a jego zewnętrznymi gestami czy słowami jest sytuacją wyjątkową od przyjętej zasady. Dlatego też jeśli ktoś twierdzi, że wyrażona przez niego zgoda małżeńska miała jedynie charakter pozorny, musi to udowodnić na forum procesowym. Sytuacja braku owej zgodności nosi nazwę symulacji i powoduje nieważność małżeństwa. Zgodnie bowiem z paragrafem 2 cytowanego już wyżej kan. $1101 \mathrm{KPK}$ : „Jeśli jednak jedna ze stron albo obydwoje pozytywnym aktem woli wykluczyłyby samo małżeństwo lub jakiś istotny element małżeństwa, albo jakiś istotny przymiot, zawierają je nieważnie".

Powyższa norma zawiera dwa niezwykle istotne elementy. Po pierwsze, rozróżnia przedmiot symulacji, nadając mu trojaki charakter. Po drugie, wskazuje na „pozytywny akt woli” jako niezbędny do uznania działania osoby zawierającej małżeństwo jako symulowane.

Wyrażenie ,pozytywny akt woli” oznacza, iż nie jest wystarczający do stwierdzenia symulacji brak u nupturienta woli zawarcia małżeństwa, ale konieczna jest pozytywna wola wykluczenia małżeństwa lub jednego z istotnych elementów albo przymiotów małżeństwa. Symulacja dokonuje się aktem pozytywnym woli. W ten sposób wyklucza się akt negatywny. Symulant, wybierając świadomie taki akt woli, wywołuje konflikt pomiędzy swoim stanem wewnętrznym a pozorami zewnętrznymi. Zatem pozytywnym działaniem woli dokonuje aktu fałszywego. Jest on formą antyzgody małżeńskiej (Góralski 2000, 102-103).

Symulacja może mieć jako przedmiot albo samo małżeństwo, albo jeden $\mathrm{z}$ istotnych elementów lub przymiotów małżeństwa. W pierwszym przypadku mamy do czynienia $\mathrm{z}$ symulacją całkowitą, $\mathrm{w}$ drugim zaś - $\mathrm{z}$ symulacją częściową. Ze względu na postawione w tytule niniejszego artykułu zagadnienie właśnie symulacja częściowa stanowi przedmiot naszego szczególnego zainteresowania, i to ta, która dotyczy bezpośrednio jednego z istotnych elementów małżeństwa, jakim jest bonum coniugium, czyli dobro małżonków.

Małżeństwo stwarza zgoda stron, czyli akt woli, „którym mężczyzna i kobieta w nieodwołalnym przymierzu wzajemnie się sobie oddają i przyjmują w celu stworzenia małżeństwa" (kan. 1057 § 2 KPK). Tenże akt woli zakłada przede wszystkim pełną determinację nupturientów ukierunkowaną na wzajemne doskonalenie się w zakresie duchowym, intelektualnym, uczuciowym czy fizycznym, czyli stałą determinację woli w celu zapewnienia dobra swojego współmałżonka. Zatem można stwierdzić, iż nie wyraża w sposób ważny zgody małżeńskiej ten, kto wyklucza 
ze swojego małżeństwa „dobro współmałżonka”, czyli wspólnotę ich życia, gdyż w ten sposób wyklucza możliwość stworzenia relacji międzyosobowej stanowiącej podstawę zaistnienia małżeństwa. Stąd można powiedzieć, że intentio przeciwko ordinatio ad bonum coniugum polega na wykluczeniu wzajemnego oddania się i przyjęcia małżonków w celu stworzenia przez nich małżeństwa.

W kanonie $1055 \mathrm{KPK}$, który z pewnością jest punktem centralnym rozważań dotyczących interpretacji terminu exclusio boni coniugum, stwierdza się, że małżeństwo skierowane jest ze swej natury na dobro małżonków, dla których staje się ono pierwszorzędnym celem. Zatem ktoś, kto zawierając związek małżeński z drugą osobą, pragnie stworzyć prawdziwą wspólnotę miłości, musi dążyć do wzajemnego doskonalenia się - ono staje się nie tylko spoiwem małżeństwa, lecz przede wszystkim narzędziem tworzenia wzajemnego dobra, o którym z takim pietyzmem mówi kan. $1055 \mathrm{KPK}$. Taka koncepcja małżeństwa, pojmowanego jako consortium totius vitae, opartego na wspólnym dążeniu do doskonałości, zawiera $\mathrm{w}$ sobie utrwaloną $\mathrm{w}$ tradycji ideę mutuum adiutorium. W takim rozumieniu małżeństwa dobro małżonków musi być związane z chrześcijańską koncepcją miłości małżeńskiej oraz prawem małżonków do wspólnego życia, czyli communio vitae. Dlatego wydaje się, że wykluczenie dobra małżonków oznacza negację - poprzez pozytywny akt woli wyrażony w stosunku do drugiej osoby - prawa do stworzenia wspólnoty życia i miłości, niezależnie od tego, czy dana osoba czyni to explicite, czy jedynie implicite (Leszczyński 2002, 107-109).

Zastanawiając się nad praktycznym wymiarem tego terminu należy stwierdzić, że jeśli ktoś, dla przykładu, zawiera związek małżeński jedynie po to, aby w swoim egoistycznym podejściu do życia korzystać z usług domowych żony, odmawiając jej jakiejkolwiek więzi uczuciowej czy wręcz wspólnego zamieszkania, możemy mówić o wykluczeniu dobra małżonka. Jeśli ktoś odmawia drugiej osobie pełnej relacji międzyosobowej na płaszczyźnie fizycznej i seksualnej, mamy do czynienia z podobną sytuacją. Mówiąc ogólnie, pojęcie bonum coniugum zawiera w sobie tę całą gamę zachowań, uczuć i sytuacji, które służą stworzeniu prawdziwej relacji międzyosobowej opartej na miłości i wzajemnym doskonaleniu się małżonków ${ }^{3}$.

${ }^{3}$ W. Góralski, pisząc o pojęciu bonum coniugium, stwierdza: „Prawo do wspólnoty życia obejmuje to wszystko, co jest niezbędne do nawiązania relacji międzyosobowych pomiędzy małżonkami. Wykluczenie więc jakiegokolwiek z elementów umożliwiających takie relacje, np. wspólnego zamieszkania, byłoby przyczyną nieważności małżeństwa. W szczególności, jak zauważa O. Fumagalli Carulli, należy tutaj brać pod uwagę moment dobra małżonków, uwarunkowanego wspomnianymi relacjami. Zakłada ono, zdaniem wymienionej autorki, przede wszystkim trzy istotne aspekty, których wykluczenie powodowałoby nieważność umowy małżeńskiej: traktowanie współmałżonka jako osoby, wspólnotę dwóch osób, pragnienie dobra dla współmałżonka" (Góralski 2000, 104). 


\section{DOWODZENIE WYKLUCZENIA DOBRA MAŁŻONKÓW}

Dowodzenie w sprawach z tytułu wykluczenia dobra małżonków winno opierać się (biorąc zawsze pod uwagę tzw. circumstantiae zawarcia małżeństwa) na kilku podstawowych elementach. Najważniejszym z nich jest confessio iudicialis, a ponadto niezwykle istotne są zeznania świadków oraz określenie tzw. causa simulandi, czyli przyczyny, która może powodować wykluczenie pozytywnym aktem woli dobra wspólnego małżonków. Spróbujmy pokrótce spojrzeć na każdy ze wskazanych elementów dowodzenia.

\subsection{Confessio iudicialis}

Confessio, czyli przyznanie się, jest to stwierdzenie jakiegoś faktu, na piśmie lub ustnie, dokonane przeciwko sobie przez którąs ze stron co do samego przedmiotu sprawy (kan. $1535 \mathrm{KPK}$ ). Zatem elementem charakteryzującym confessio jest tzw. animus confitendi, czyli świadomość dążenia do ukazania prawdy nawet za cenę pogorszenia swojej pozycji w procesie. Aktualnie obowiązujący Kodeks prawa kanonicznego rozróżnia dwie formy confessio: confessio iudicialis, czyli przyznanie się dokonane wobec sędziego (kan. $1535 \mathrm{KPK}$ ) oraz confessio extraiudicialis, czyli przyznanie się dokonane w sądzie, jednak wobec osoby trzeciej (kan. 1537 KPK). Warto zauważyć, iż Codex Iuris Canonici z 1917 r. zgodnie z kan. 1750 zakładał, iż jedyną możliwą formą oświadczenia stron posiadającą moc dowodową w procesie spornym jest tzw. confessio iudicialis.

Confessio iudicialis, nazywane przez niektórych autorów regina probationum, przez innych zaś probatio probatissima, zawdzięcza swoją wyjątkową pozycję pośród różnych środków dowodowych temu, iż nikt, kto występuje w procesie jako strona, nie może być zainteresowany potwierdzaniem faktów, które w rzeczywistości działają na jego niekorzyść. Stąd zaistnienie tego rodzaju sytuacji było bardzo istotnym dowodem prawdziwości faktów przedstawionych przez stronę przeciwną. Confessio iudicialis w sprawach o charakterze publicznym, do których należą również sprawy o stwierdzenie nieważności małżeństwa, nie posiadało nigdy mocy dowodu pełnego ${ }^{4}$. Mogło się bowiem zdarzyć, że dobro prywatne stron zaangażowanych $\mathrm{w}$ proces o stwierdzenie nieważności małżeństwa było przeciwne dobru publicznemu, jakim jest i zawsze pozostanie rzeczywiste stwierdzenie, czy małżeństwo danych osób zaistniało czy nie. W przypadku zatem niezgodności istniejącej pomiędzy interesem stron i dobrem publicznym confessio iudicialis praktycznie pozbawione było swojej wartości. Dlatego też

${ }^{4}$ Jedynym wyjątkiem były sprawy dotyczące impotencji i małżeństwa niedopełnionego definiowane przez kan. 1975 Kodeksu prawa kanonicznego z 1917 r. W przypadku braku innych dowodów confessio iudicialis stanowiła dowód pełny pod warunkiem przedstawienia tzw. testes septimae manus, potwierdzających wiarygodność zeznań strony. 
w procesie o stwierdzenie nieważności małżeństwa poddane było licznym warunkom, określającym formę jego składania (Leszczyński 2000, 109-111). Wartość dowodowa oświadczeń stron została zdefiniowana przez aktualnie obowiązujący Kodeks prawa kanonicznego w kan. 1536, 1537 i $1679^{5}$.

W drugim paragrafie kanonu 1536, dotyczącym spraw o charakterze publicznym, dokonuje się bardzo ważnego rozróżnienia pomiędzy ,przyznaniem się sądowym" a innymi formami oświadczeń stron. Samo rozróżnienie nie jest bez wątpienia nowością wprowadzoną przez kodeks z 1983 r. Nowością natomiast jest postawienie na tym samym poziomie, przynajmniej teoretycznie, ,„przyznania się sądowego" oraz innych form oświadczeń stron, które nie stanowią przyznania się. Wszystkie one bowiem posiadają - w myśl kan. $1536 \mathrm{KPK}$ - moc dowodową, której wartość winna być określona w konkretnym przypadku przez sędziego. On też w ocenie wartości dowodowej poszczególnych oświadczeń stron winien wziąć pod uwagę wszystkie inne okoliczności sprawy, a także inne środki dowodowe, takie jak zeznania świadków, opinie biegłych czy istniejące dokumenty. Warto jednak zauważyć, że norma kan. 1536 KPK nie stwierdza, że wszystkie formy oświadczeń stron muszą posiadać tę samą moc dowodową. Decyzję co do ich wartości pozostawia ona sędziemu. W związku z tym jest możliwa w sytuacja, w której przyznanie się sądowe będzie stanowić najbardziej przekonujący dowód dla sędziego. Istotne jest jednak to, że owa wyższość przyznania się sądowego, czyli confessio iudicialis, nad innymi formami oświadczeń stron, teoretycznie możliwa, nie została zapisana w normie.

Inną nowością kan. 1536 KPK jest określenie pewnych limitów, jakim podlega sędzia w nadaniu wartości dowodowej poszczególnym formom oświadczeń stron. Jak stwierdza się bowiem w kan. 1536 KPK, sędzia nie może przyznać oświadczeniom mocy pełnego dowodu, chyba że dochodzą inne elementy, które ostatecznie je wzmacniają. Stąd, pomimo że poszczególne oświadczenia stron posiadają przyznaną przez kodeks wartość dowodową, ich ocena musi mieć charakter relatywny w odniesieniu do innych elementów, które mogą je wzmocnić lub osłabić. Wypada zatem w tym miejscu zadać sobie pytanie: co kryje się pod terminem ,inne elementy” użytym w kan. 1536 KPK?

Wyjaśnienie terminu ,inne elementy” nie jest z pewnością zadaniem łatwym ze względu na bardzo różnorodną jego interpretację w opinii poszczególnych autorów. Z pewnością termin ten nie oznacza ,innych dowodów”, ponieważ jeśliby tak było, to cały nowatorski charakter kan. 1536 KPK straciłby na wartości. Pomocą dla zrozumienia terminu ,inne elementy” może być norma zawarta w kan. 1679 KPK: „Jeśli nie ma skądinąd pełnych dowodów, sędzia, dla oceny zeznań stron według przepisu kan. 1536, powinien się posłużyć, jeżeli to możliwe, świadkami co do prawdomówności samych stron, oprócz innych poszlak i wskazówek".

${ }^{5}$ Warto w tym miejscu zauważyć, że oświadczenia stron złożone pod wpływem przymusu i ciężkiej bojaźni, jak i zawierające błąd faktyczny, w myśl kan. 1538 KPK pozbawione są jakiejkolwiek mocy dowodowej (por. również kan. 125 i 126 KPK). 
Wydaje się, że w kodeksie, używając pojęcia testes credibilitate, ma się na względzie osoby, które ze względu na szczególny przykład moralności czy pozycję, którą zajmują we wspólnocie Kościoła (duchowni, osoby konsekrowane), mogą zaświadczyć o prawdomówności samych stron. Jest rzeczą zrozumiałą, że osoba taka winna na tyle znać strony, czy też jedną z nich, aby móc z czystym sumieniem zaświadczyć o ich prawdomówności. I choć argument ten ma charakter bardziej moralny niż prawny, wydaje się istotny, szczególnie w sprawach, w których oświadczenia stron stanowią podstawowy środek dowodowy. Warto w tym miejscu zauważyć, że w kan. 1679 KPK używa się określenia si fieri potest, w związku z tym odwołanie się przez sędziego do tzw. testes credibilitate nie ma charakteru absolutnego i dlatego możliwa jest sytuacja, w której sędzia mógłby nadać oświadczeniom stron moc dowodu pełnego, bez odwołania się do świadków prawdziwości ich zeznań, o ile tylko zeznania te byłyby wzmocnione innymi poszlakami czy wskazówkami.

\subsection{Zeznania świadków}

Z pewnością środkiem dowodowym, który może wzmocnić przyznanie się sądowe jednej ze stron są zeznania świadków. Kodeks z 1983 r. w kan. 1572 wskazuje na kilka elementów niezwykle istotnych w ocenie wartości dowodowej zeznań świadków. Sędzia, wartościując zeznania, winien wziąć pod uwagę przede wszystkim to, jaki jest stan osoby i jaka jest jego uczciwośćc; czy świadek zeznaje na podstawie własnej wiedzy, zwłaszcza z osobistego widzenia i słyszenia, czy też wiedzy innych osób; czy świadek jest stały i trwale ze sobą zgodny, czy też zmienny, niepewny i chwiejny oraz czy jego zeznania są zgodne z innymi zeznaniami świadków i potwierdzone przez inne elementy dowodowe. Wszystkie wymienione przez kodeks elementy - zarówno subiektywne, jak i obiektywne mają dopomóc sędziemu w ocenie wartości dowodowej zeznania świadka, nie mogą jednak dyspensować samego sędziego od dokonania oceny, która dotyczy wyłącznie jego osoby.

Warto w tym miejscu zaznaczyć, iż zgodnie z kan. 1573 KPK ,zeznanie jednego świadka nie może być pełnym dowodem". Taka sytuacja mogłaby zaistnieć wówczas, gdyby w sprawie, o której mowa, sędziemu nie udałoby się uzyskać przyznania sądowego jednej ze stron, a sędzia dysponowałby jedynie zeznaniem jednego świadka. Zeznanie jednego świadka nie stanowi dowodu pełnego, chyba że - i tutaj kodeks przewiduje dwa wyjątki od tradycyjnej reguły testis unus,

${ }^{6}$ Odnośnie uczciwości świadka J. J. García Failde pisze: „Ha de tenerse muy en cuenta la veracidad de la que dé muestras el testigo. Para ello es importante concocer sul modo de ser, sus costumbres, su religiosidad práctica, etc. Pero non debe exagerarse hasta el extremo de establecer una correlación poco menos que necesaria entre buenas/malas costumbres, etc., y veracidad/no veracidad del testigo: personas hay que, a pesar de sus malas costumbres [...], son veraces y que, non obstante sus buenas costumbres [...], no son veraces" (García Failde 1984, 140). 
testis nullus - „chodzi o świadka kwalifikowanego, który zeznaje w sprawach dokonanych z urzędu, albo okoliczności rzeczy lub osób sugerują inaczej”. Zatem kodeks, dla zagwarantowania wolnej oceny dowodów ze strony sędziego, daje możliwość przyznania zeznaniu nawet jednego świadka dowodu pełnego, o ile świadek ten zeznaje o sprawach dokonanych z urzędu lub o innych, o ile jego zeznanie zostanie potwierdzone przez inne elementy dowodowe (Arroba Conde 1993, 385).

\subsection{Causa simulandi}

Kolejnym elementem, niezwykle istotnym w ocenie zaistnienia wykluczenia dobra małżonków, jest określenie tzw. causa simulandi, czyli wskazanie na konkretną sytuację podmiotu, która popycha go do wykluczenia pozytywnym aktem woli tego konkretnego elementu małżeństwa. Idzie zatem o wskazanie logicznej zależności przyczynowej pomiędzy sytuacją obiektywną lub subiektywną podmiotu a jego działaniem intencjonalnym. Jest rzeczą oczywistą, iż causa simulandi nie jest rozpatrywana w sensie absolutnym, lecz względnym, tzn. w odniesieniu do konkretnego podmiotu, który postanawia wykluczyć dobro wspólne małżonków. I tak, dla przykładu, taka przyczyna może być umiejscowiona w komfortowej sytuacji życia, do której przywykła dana osoba, dla której egoistyczne nastawienie do życia, podporządkowanie ludzi i wartości własnym celom jest tak ważne i nieusuwalne, że jakakolwiek zmiana wydaje się ograniczeniem własnej osobowości. Może się zdarzyć, iż wskutek procesu dojrzewania jakiekolwiek otwarcie się uczuciowe na drugą osobę nie wydaje się możliwe i dlatego dana osoba, chcąc zawrzeć małżeństwo, wyklucza jednocześnie jakąkolwiek relację uczuciową ze swoim partnerem czy partnerką, sprowadzając małżeństwo jedynie do sfery czysto formalnej, zewnętrznej, pozbawionej tej sfery związku, która skądinąd wydaje się fundamentalna. Również kwestia wykluczenia zachowania indywidualności myślenia, dotychczasowego stylu życia, własnej przeszłości może spowodować wykluczenie z integralności związku pewnych sfer życia, dla przykładu intymnego, uniemożliwiając nawiązanie pełnej wspólnoty życia i miłości. Wydaje się, że uwarunkowania umysłowo-emocjonalne mogą dostarczać wiele sytuacji, które w założeniu mogą stanowić o zaistnieniu konkretnej przyczyny powodującej wykluczenie przez daną osobę dobra wspólnego małżonków i nawiązanie przez nich głębokiej relacji interpersonalnej.

W odniesieniu do określenia causa simulandi podstawową wartość mają oczywiście zeznania samych stron, a zwłaszcza confessio iudicialis. Trudno bowiem wymagać od świadków wiedzy dotyczącej konkretnych faktów świadczących o przyczynie, dla której dana osoba dopuszcza się symulacji, zwłaszcza jeśli idzie o historyczne określenie logiki faktów. Wydaje się, że w większości przypadków nie jest to możliwe, gdyż wiedza świadków zasadniczo nie wkracza w pokłady intymnej i często nieznanej zewnętrznie relacji pomiędzy stronami oraz ich prawdziwych 
intencji odnośnie do wykluczenia małżeństwa czy któregoś z jego elementów lub przymiotów. Idzie raczej o stwierdzenie logiki postępowania danej osoby w obliczu woli wykluczającej, obecnej podczas wyrażania zgody małżeńskiej. Wystarczy zatem, aby świadkowie przedstawili fakty sobie znane, bez dokonywania jakiejkolwiek ich interpretacji, gdyż one same - czasami nawet nie w pełni zgodne - mogą, w zestawieniu z zeznaniami stron, przekonać sędziego i ukształtować jego pewność moralną co do istnienia causa simulandi $\mathrm{w}$ danym przypadku.

Niezwykle ważne dla określenia tzw. causa simulandi jest zestawienie jej z tzw. causa contrahendi, choć trzeba przyznać, że nie zawsze jest to proste, zwłaszcza jeśli chodzi o wskazanie, jaka intencja przeważa: wola zawarcia małżeństwa czy wola wykluczenia z niego dobra małżonka. Trudne bowiem, co trzeba przyznać, jest samo rozgraniczenie woli wykluczenia małżeństwa jako takiego od wykluczenia jego elementu, jakim jest bonum coniugum.

\section{WNIOSKI}

Obecnie obowiązujący Kodeks prawa kanonicznego pod pojęciem symulacji częściowej rozumie wykluczenie jakiegoś istotnego elementu małżeństwa lub jakiegoś istotnego przymiotu małżeństwa. W projektach nowego Kodeksu prawa kanonicznego podczas powstawania norm dotyczących symulacji częściowej mówiło się najpierw o ius ad vitae communionem, by następnie zastąpić tę formułę inną, tzn. ius ad ea quae vitae communionem essentialiter constituunt. Obie formuły zostały jednak porzucone, głównie z tego powodu, że nie współgrały z koncepcją małżeństwa, o której mowa w cytowanym wyżej kan. 1055 KPK. Pozostały natomiast wątpliwości wynikające $\mathrm{z}$ faktu, iż termin bonum coniugum, będący przedmiotem symulacji częściowej, zawiera się w koncepcji symulacji całkowitej, ujmującej małżeństwo właśnie jako consortium totius vitae. Co więcej, jurysprudencja rotalna rozpatruje sprawy, w których ma miejsce wykluczenie dobra małżonków z tytułu symulacji całkowitej.

Wydaje się, że pozbawianie zastosowania tytułu wykluczenia dobra małżonków w orzecznictwie trybunałów kościelnych nie jest słuszne, choćby dlatego, że teoretycznie przecież jest możliwe, że dana osoba może pragnąć małżeństwa, a jednocześnie wykluczyć pozytywnym aktem woli jakiś istotny element relacji międzyosobowej z drugą osobą, jakim może być chociażby wspólne zamieszkanie czy więź emocjonalna, osobowa. Oczywiście należy zdawać sobie sprawę, że granica, jaka przebiega pomiędzy przedmiotem wykluczenia małżeństwa a przedmiotem wykluczenia dobra małżonków jest bardzo płynna i trudna do określenia, ale wydaje się, iż w tym przypadku zadaniem sędziego jest określenie, z którą figurą symulacji ma do czynienia i jaki jest przedmiot symulacji.

Jest jeszcze jeden niezwykle istotny element argument przemawiający za istnieniem wykluczenia dobra małżonków jako figury autonomicznej, mianowicie wola 
prawodawcy. Skoro prawodawca w kan. $1101 \S 2$ KPK określił, iż przedmiotem symulacji częściowej jest jakiś istotny przymiot małżeństwa lub jakiś istotny element małżeństwa, to wydaje się zubożeniem sprowadzanie tytułu wykluczenia jakiegoś istotnego elementu małżeństwa jedynie do tytułu wykluczenia potomstwa. Naszym zdaniem dobrze się stało, iż prawodawca postanowił wyróżnić taką formę symulacji, gdyż w ten sposób ujęta została koncepcja wykluczenia więzi międzyosobowej, która niekoniecznie pokrywa się z wykluczeniem małżeństwa jako takiego.

Biorąc pod uwagę normę kodeksową wprowadzoną przez prawodawcę, a zarazem zdanie wielu przedstawicieli doktryny prawnej, należy mieć nadzieję, iż tytuł ten i w jurysprudencji doczeka się precyzyjnych rozwiązań.

\section{BIBLIOGRAFIA}

\section{Źródla}

Codex Iuris Canonici auctoritate Ioannis Pauli PP. II promulgatus. 1984. Przekł. polski zatwierdzony przez Konferencję Episkopatu. Poznań: Pallottinum.

Pontificia Commisio Iuris Canonici Reconoscendo. 1977. Communicationes 9: 123.

Pontificia Commisio Iuris Canonici Reconoscendo. 1983. Communicationes 15: 221.

Sent. coram Fagiolo (30 października 1970). 1970. Sacrae Romanae Rotae Decisiones seu Sententiae 62: 878-990.

Sent. coram Pinto (23 listopada 1979). 1980. Monitor Ecclesiasticus 105: 393.

Sobór Watykański II. 2002a. „Konstytucja dogmatyczna o Kościele Lumen gentium”. W Sobór Watykański II. Konstytucje, dekrety, deklaracje. 104-166. Poznań: Pallottinum.

Sobór Watykański II. 2002b. „Konstytucja duszpasterska o Kościele w świecie współczesnym Gaudium et spes". W Sobór Watykański II. Konstytucje, dekrety, deklaracje. 526-606. Poznań: Pallottinum.

\section{Literatura}

Arroba Conde, Manuel. 1993. Diritto processuale canonico. Roma: Ediurcla.

Bertolino, Rinaldo. 1996. „Gli elementi costitutivi del bonum coniugum: stato della questione”. W Il bonum coniugum nel matrimonio canonico. 7-32. Città del Vaticano: Libreria Editrice Vaticana.

Bonnet, Pier Antonio. 1996. „Il bonum coniugum e l'essenza del matrimonio”. W Il bonum coniugum nel matrimonio canonico. 89-135. Città del Vaticano: Libreria Editrice Vaticana.

Gajda, Piotr Mieczysław. 2000. Prawo matżeńskie Kościoła katolickiego. Tarnów: Wydawnictwo Biblos.

García Failde, Juan Jose. 1984. Nuevo derecho procesal canónico. Salamanca: Universidad Pontificia de Salamanca.

Góralski, Wojciech. 2000. Kanoniczne prawo matżeńskie. Warszawa: Polskie Wydawnictwo Prawnicze Iuris.

Leszczyński, Grzegorz. 2000. „Oświadczenia stron jako środek dowodowy w procesie o stwierdzenie nieważności małżeństwa". Prawo Kanoniczne 43 (1-2): 107-121.

Leszczyński, Grzegorz. 2002. „Niedojrzałość emocjonalna a wykluczenie dobra małżonków”. Ius Matrimoniale 7 (13): 87-110.

Viladrich, Pedro Juan, 2002. Konsens matżeński. Sposoby prawnej oceny i interpretacji $w$ kanonicznych procesach o stwierdzenie nieważności matzeństwa. Warszawa: Wydawnictwo Uniwersytetu Kardynała Stefana Wyszyńskiego. 


$$
\text { pr. Grzegorz Leszczyński }
$$

\title{
THE GOOD OF SPOUSES AS OBJECT OF SIMULATION OF THE MARRIAGE CONSENT
}

\begin{abstract}
The Code of Canon Law of 1983 classifies the reasons for marriage invalidity in three different categories: diriment impediments, defects in matrimonial consent and a lack or a defect of the canon form. In $1101 \S 2$ the Code of Canon Law enumerates different forms of simulations among different defects in matrimonial consent. Simulation signifies that a person contracting marriage expresses a marital agreement merely on the surface, excluding in reality through a positive act of the will the marriage itself or its essential element or an essential quality of the marriage. The present article is an attempt to look at the relation existing between the validity of marriage and the exclusion of the good of spouses, with the consideration of the object of the simulation form and the ways of delivering proof of it.
\end{abstract}

Keywords: marriage, matrimonial consent, simulation, good of spouses, exclusion. 